\title{
Rancang Bangun Aplikasi Audit Mutu Akademik Internal Universitas Sam Ratulangi Berbasis Web
}

\author{
Viastri Rindengan, Arie Lumenta, Yaulie Rindengan \\ Informatics Engineering, Sam Ratulangi University, Manado, Indonesia \\ E-mail : viastririndengan@gmail.com, al@ unsrat.ac.id, rindengan@unsrat.ac.id
}

\begin{abstract}
Dalam meningkatkan kualitas, Universitas Sam Ratulangi melalui lembaga penjaminan mutu menyelenggarakan audit yang disebut audit mutu akademik internal. Salah satu tujuannya adalah untuk memeriksa kesesuaian antara standar mutu yang ditetapkan. Proses di Universitas Sam Ratulangi saat ini masih belum terkomputerisasi secara sepenuhnya. Beberapa diantaranya masih bersifat manual. Tim Audit Universitas Sam Ratulangi harus membuka dokumen satu persatu untuk menemukan data yang diinginkan. Oleh karena itu, dibuatlah aplikasi audit mutu akademik internal yang dapat membantu proses Audit Internal Mutu di Universitas Sam Ratulangi. Berdasarkan proses auditnya mulai pengolahan data audit menjadi lebih cepat dan mudah dilakukan. Metode yang digunakan sebagai tahapan penelitian adalah metodologi Rapid Aplication Development(RAD) yang merupakan metode proses perangkat lunak yang tahapan fase yang singkat. Semua pihak yang terlibat di dalam audit tidak perlu lagi menggunakan kertas. data audit juga menjadi lebih mudah dan cepat.
\end{abstract}

Kata Kunci : Audit Mutu, Php, Rapid Application Development (RAD), Web

\section{Pendahuluan}

Dengan berkembangnya zaman yang sudah modern saat ini, sistem informasi sangatlah di butuhkan dalam melakukan proses pengerjaan, untuk menunjang kinerja dari sebuah universitas. Sistem informasi dapat menjadikan sebuah pekerjaan menjadi lebih terstruktur dan mengurangi kesalahankesalahan yang berdampak buruk pada kinerja pada suatu universitas. Pada bagian ini terdapat sistem informasi yang masih belum digital yaitu pengauditan mutu akademik internal di Universitas Sam Ratulangi. Berdasarkan permasalahan tersebut dibuatlah "Rancang Bangun Aplikasi Audit Mutu Akademik Internal di Universitas Sam Ratulangi berbasis web". Dengan adanya aplikasi ini dapat membantu para tim pengaudit unsrat menjadi lebih efisien dengan aplikasi pengauditan ini. Sehingga dapat membantu dan mempercepat kinerja untuk pengauditan mutu akademik internal yang ada di universitas sam ratulangi. Aplikasi yang di hasilkan oleh sistem informasi ini adalah aplikasi yang berbasis web.

Aplikasi ini diharapkan dapat membantu tim pengaudit melakukan pengauditan dan merekap hasil pengauditan dengan baik. Aplikasi tersebut juga dapat menghasilkan informasi yang nantinya bermanfaat bagi tim pengaudit mutu akademik internal universitas sam ratulangi.

\section{LANDASAN TEORI}

\section{A. Mutu Akademik Internal Universitas Sam Ratulangi}

Standar mutu akademik unsrat merupakan pernyataan untuk mengarahkan penyusunan rencana, pelaksanaan, dan evaluasi kegiatan akademik lembaga dan sivitas akademika unsrat dengan berorientasi pada peningkatan mutu akademik secara berkelanjutan. Standar mutu akademik unsrat merupakan salah satu landasan bagi penyusunan visi, misi, tujuan dan sasaran fakultas, jurusan/bagian dan program studi serta pencapaian, tata pamong, kepemimpinan, sistem pengelolaan dan penjaminan mutu, mahasiswa dan lulusan, sumber daya manusia, kurikulum, pembelajaran, dan suasana akademik pembiayaan sarana dan prasarana serta system informasi, penelitian, pengabdian kepada masyarakat dan kerjasama. Standar mutu akademik berisi asas penyelenggaraan kegiatan akademik di lingkungan unsrat yang merupakan dasar dalam perencanaan, pelaksanaan, monitoring, dan evaluasi kegiatan akademik. Standar mutu akademik menjadi dasar pelaksanaan kegiatan akademik unsrat yang berorientasi pada perkembangan global dengan pendekatan yang tidak meninggalkan kekayaan budaya local dan bangsa Indonesia pada umumnya.

B. Database

Menurut Kristanto (2004:10) pengertian Basis Data (Database) adalah kumpulan data yang disimpan secara sistematis di dalam komputer dan dapat diolah atau dimanipulasi menggunakan perangkat lunak (program aplikasi) untuk menghasilkan informasi. Pendefinisian basis data meliputi spesifikasi berupa tipe data, struktur, dan juga 
batasan-batasan data yang akan disimpan. Basis data merupakan aspek yang sangat penting dalam sistem informasi dimana basis data merupakan gudang penyimpanan data yang akan diolah lebih lanjut. Basis data menjadi penting karena dapat menghidari duplikasi data, hubungan antar data yang tidak jelas, organisasi data, dan juga update yang rumit.

\section{PHP}

Menurut Swastika (2006) PHP adalah bahasa pemrograman yang digunakan secara luas untuk penanganan pembuatan dan pengembangan sebuah web dan biasa digunakan pada HTML. PHP merupakan singkatan dari "PHP: Hypertext Preprocessor", dan merupakan bahasa yang disertakan dalam dokumen HTML, sekaligus bekerja di sisi server (server-side HTML-embedded scripting). Artinya sintaks dan perintah yang diberikan akan sepenuhnya dijalankan di server tetapi disertakan pada halaman HTML biasa, sehingga scriptnya tak tampak disisi client. Secara keseluruhan, PHP lebih sederhana dibandingkan dengan $\mathrm{C}$ karena PHP tidak menggunakan konsep yang njlimet seperti $\mathrm{C}$. selain itu PHP tidak seperti C, dimana PHP tidak memiliki fitur pemrograman low level untuk langsung mengakses hardware.

Salah satu kelebihan PHP adalah kemudahannya untuk berinteraksi dengan database. PHP dapat mendukung beberapa database secara langsung tanpa harus menginstal konektor seperti halnya bahasa pemrograman java. Dengan demikian PHP sangat fleksibel berhubungan dengan berbagai database.

Dari beberapa database yang paling banyak disandingkan dengan PHP adalah MySQL untuk menghubungkan PHP dengan database anda hanya perlu mengetahui nama database dan lokasinya, serta username dan password untuk menuju ke database tersebut.

\section{Rapid Application Development (RAD)}

Menurut Pressman R.S (1997:42) Rapid Application Development adalah sebuah model proses perkembangan software sekuensial linier yang menekankan siklus perkembangan yang sangat pendek. RAD menurut Bentley \& Whitten (2010) adalah strategi pengembangan sistem yang mana menekankan kecepatan pengembangan melalui keterlibatan user ekstensif dalam kecepatan, iterative (berulang), dan incremental construction dari serangkaian fungsi dari prototype sebuah sistem yang pada akhirnya akan mengalami perubahan secara bertahap menuju sistem akhir.

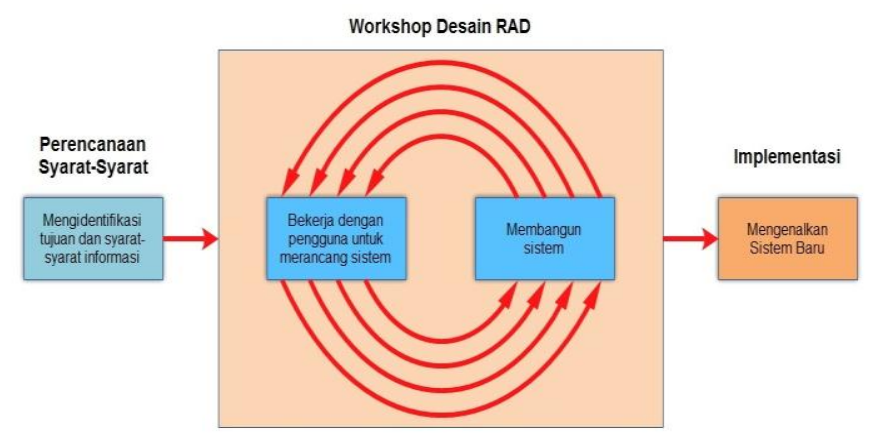

Gambar 1. Tahapan pengembangan dengan metodologi RAD

\section{Metodologi PeranCANGAN}

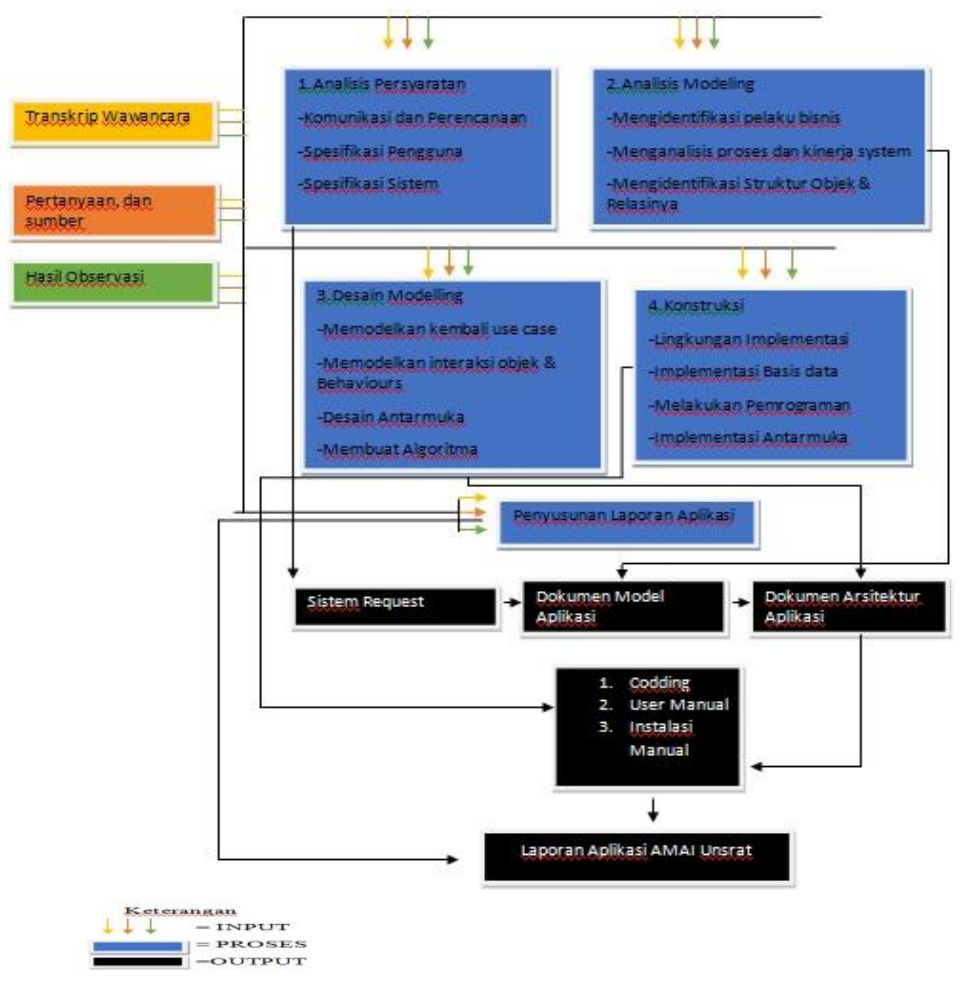

\section{A. Analisis Persyaratan}

Analisis persyaratan bertujuan untuk mengidentifikasi layanan, batasan, dan objektifitas dari sistem dari pengumpulan data yang dilakukan terhadap stakeholders. Tujuan lain adalah untuk mendefinisikan persyaratan user dan sistem.

B. Analisis Modelling

Tujuan dari fase analisis modeling adalah menganaisis semua kegiatan dalam arsitektur sistem secara keseluruhan dengan melibatkan identifikasi dan deskripsiabstraksi sistem perangkat lunak yang mendasar dan hubungan-hubungannya. Selain itu, untuk meningkatkan pemahaman terhadap permasalahan tanpa mempertimbangkan solusi teknis. Adapun hasil akhir dari analisis modeling yaitu diagram logis dari sistem yang sedang berjalan, diantaranya use case diagram.

\section{Desain Modelling}

Desain pemodelan bertujuan untuk melakukan perancangan sistem berdasarkan analisis yang telah dilakukan sebelumnya. Tahap analisis dan desain mengalami perulangan hingga diperoleh rancangan sistem yang benar-benar memenuhi kebutuhan. 
Tujuan lainnya adalah member spesifikasi jelas dan lengkap kepada programmer dan teknisi.

\section{Konstruksi}

Tujuan dari fase konstruksi adalah untuk menunjukkan platform, hardware dan software yang digunakan serta batasan dalam implementasi, serta meguji performansi prototype perangkat lunakyang telah dibangun agar dapat diketahui apakah prototype trsebut telah sesuai dengan spesifikasi analisis dan perancangan yang teah diidentifikasi sebelumnya.

\section{A. Analisis Persyaratan}

Pada tahap analisis persyaratan komunikasi dan perencanaan penelitian ini meliputi pembahasan mengenai rencana kerja penelitian

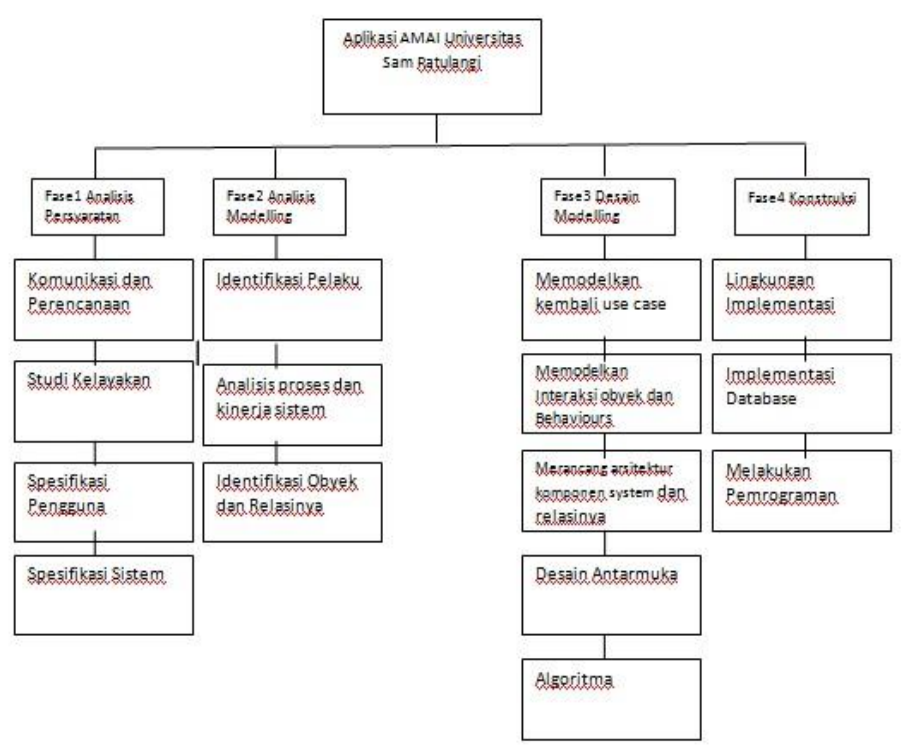

Gambar 3 Rencana Kerja Penelitian

\section{B. Analisis Modelling}

Pada tahap ini akan dilakukan analisis terhadap semua kegiatan yang terjadi pada sistem yang sedang berjalan. Tahap ini bertujuan untuk meningkatkan pemahaman terhadap permasalahan tetapi masih belum mempertimbangkan hal- hal yang bersifat teknis. Analisis pemodelan akan menggunakan tools pemodelan UML (Unified Modelling Language).

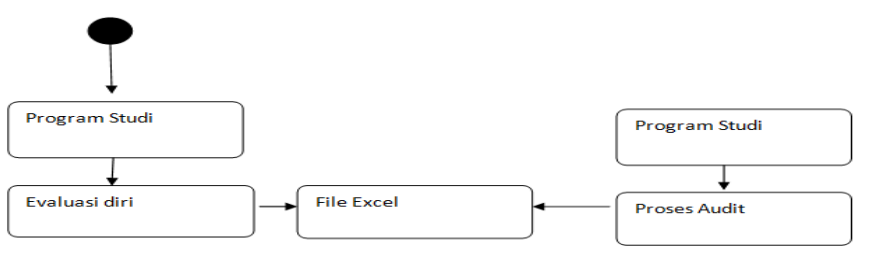

Gambar 4 Analisis Proses Bisnis pada umumnya

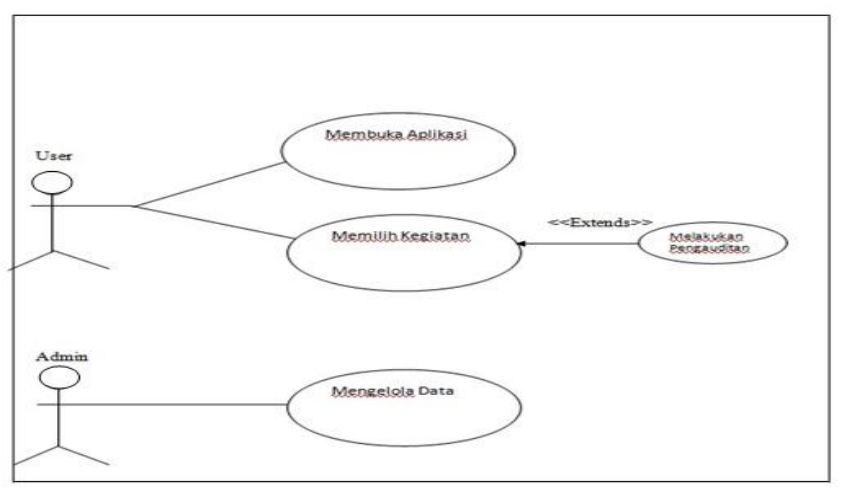

Gambar 4 Usecase Diagram

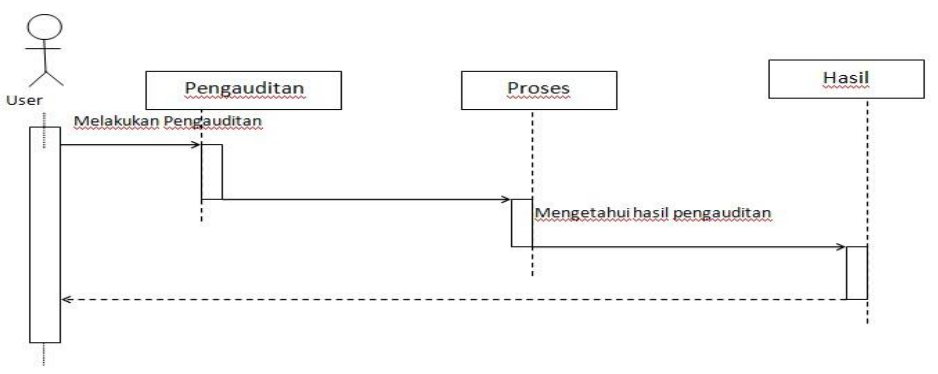

Gambar 5 Sequence Diagram

\section{Desain Modelling}

Pada fase ini bertujuan untuk melakukan perancangan sistem berdasarkan analisis yang telah dilakukan sebelumnya. Tahap analisis dan desain mengalami perulangan hingga memperoleh rancang sistem yang benar-benar memenuhi kebutuhan. Pada fase ini akan menyediakan storyboard dari aplikasi yang akan dikembangkan berikut 


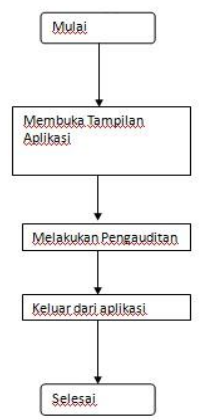

Gambar 6 Algoritma Membuka Aplikasi

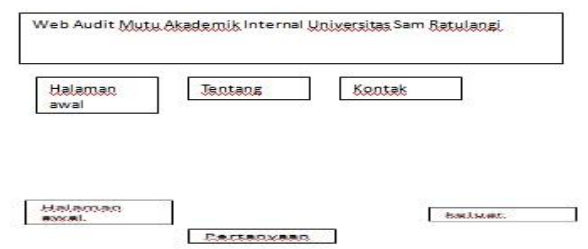

Gambar 7 Storyboard

\section{HASIL DAN PEMBAHASAN}

Berdasarkan hasil design storyboard yang telah dibuat di bab 3 maka akan dilakukan pengembangan dengan langkahlangkah antara lain, Pembuatan Database yang dilakukan pada PHP, dan Membuat Kode Program dalam software untuk membangun aplikasi pengauditan.

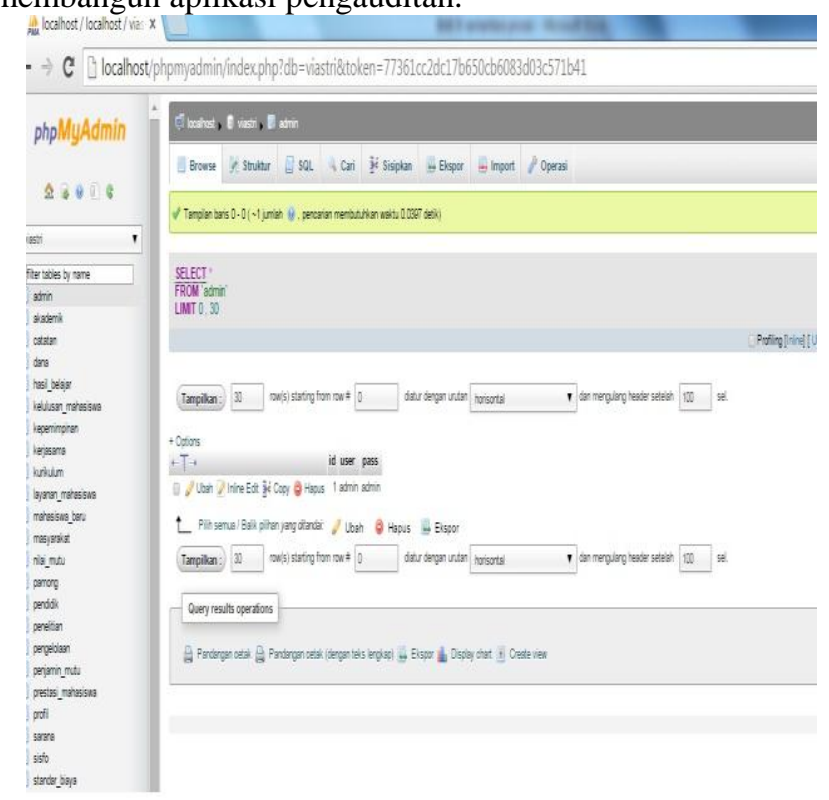

Gambar 8 Tampilan basis pada website

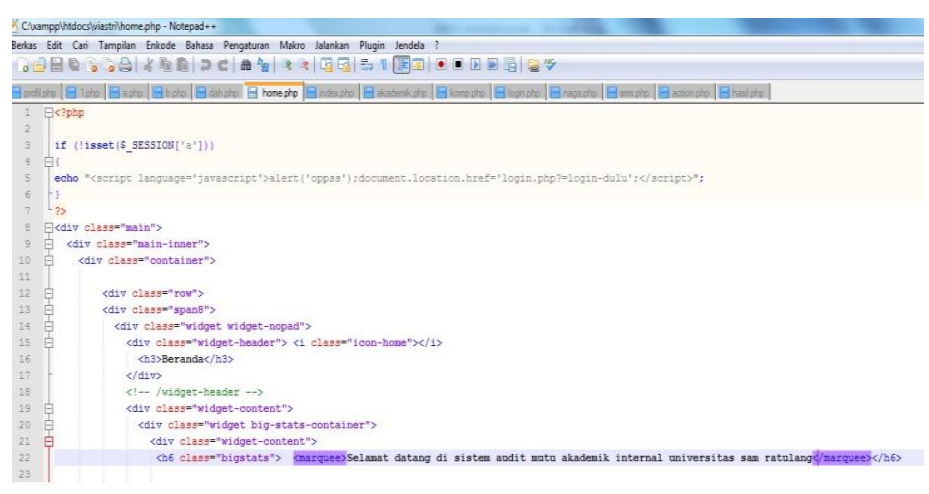

Gambar 9 Tampilan Kode Program

\section{A. Hasil}

Ini merupakan tampilan halaman $\log$ in

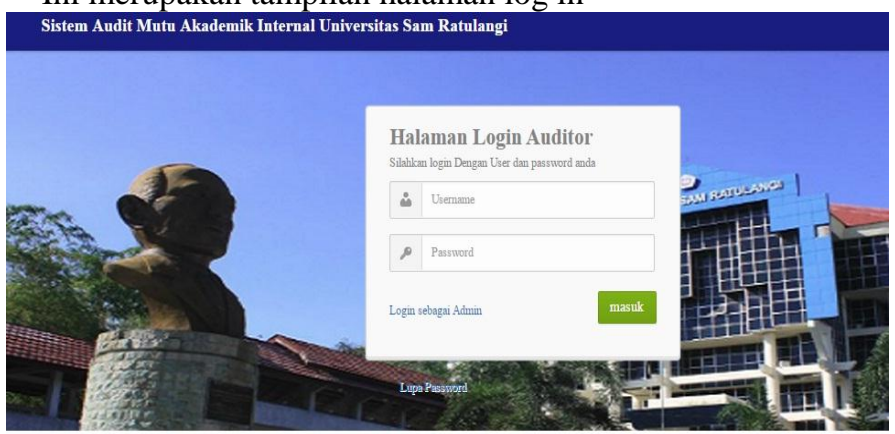

Gambar 10 halaman log in

Ini merupakan daftar pertanyaan yang akan di jawab oleh tim auditor

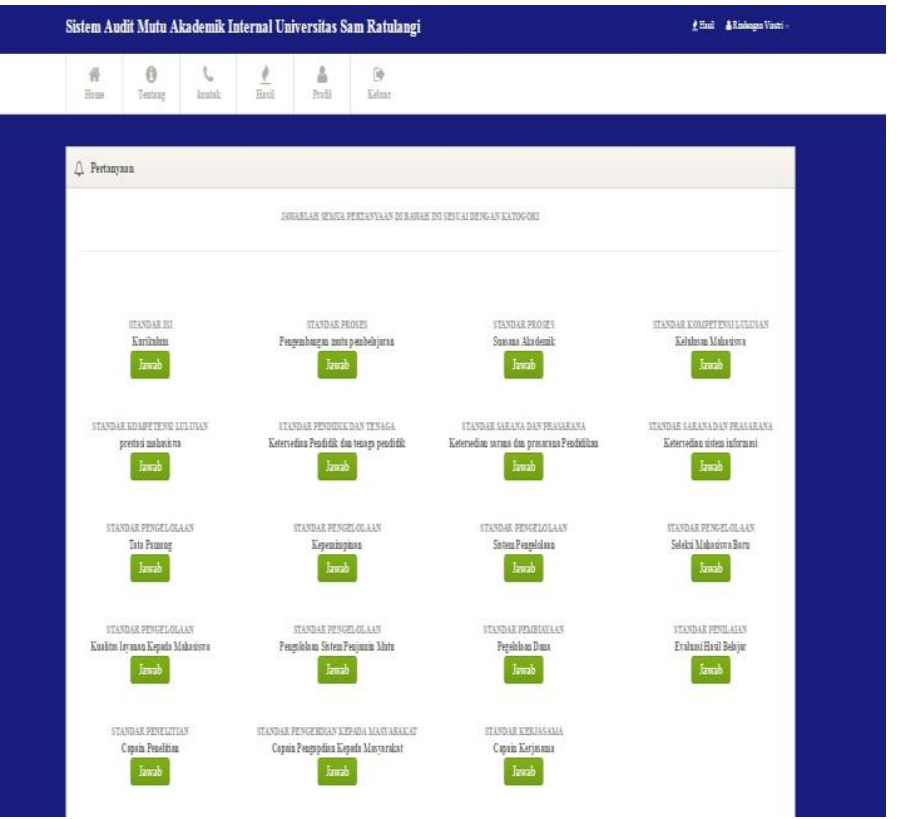




\section{Gambar 11 Daftar Pertanyaan}

Ini merupakan hasil setelah menjawab pertanyaan yang ada

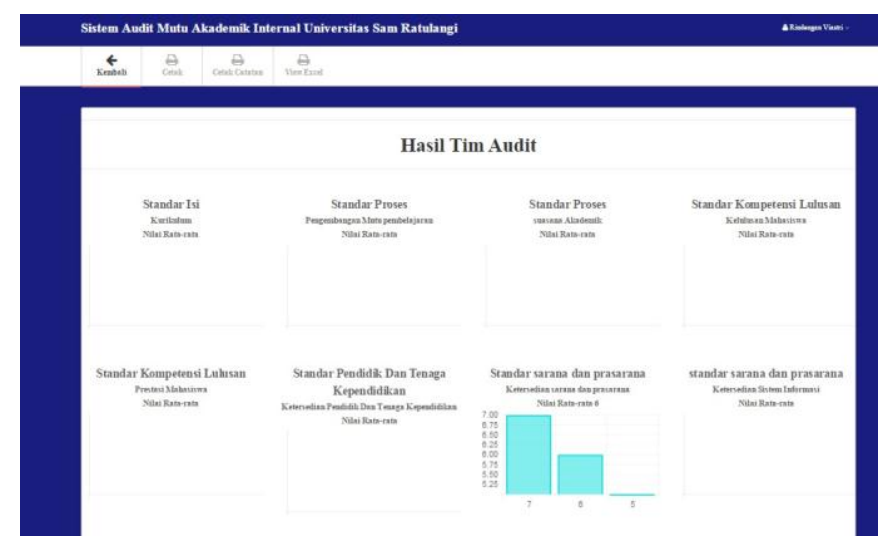

Gambar 12 Hasil dari pertanyaan

Ini merupakan berita acara atau laporan dari hasil setelah menjawab pertanyaan diatas

\section{Berita Acara Audit}

\section{Program Studi : -}

\section{Tanggal : 2015-10-18}

\section{Nama : Rindengan Viastri}

\begin{tabular}{|c|c|}
\hline Katagori & Catatan \\
\hline 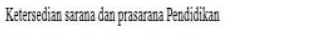 & Test satu dua tiga \\
\hline 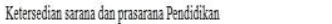 & Test satud dua tige \\
\hline
\end{tabular}

Gambar 13 Berita Acara

\section{B. Pengujian}

Kriteria prngujian sistem secara umum yaitu aplikasi dapat dijalankan dengan baik dan tidak terjadi error. Beberapa kriteria ang menjadi patokan keberhasilan sistem ini yaitu sebagai berikut:

Aplikasi yang dikembangkan sesuai dengan hasil analisis dan perancangan yang dilakukan. Fungsi atau prosedur yang di implementasikan berjalan dengan baik. Apakah sistem telah siap pakai.

\begin{tabular}{|c|c|c|c|c|c|}
\hline \multirow[t]{2}{*}{ No } & \multirow[t]{2}{*}{ Item Pengujian } & \multirow[t]{2}{*}{ Aksai } & \multicolumn{2}{|l|}{ Hasil } & \multirow{2}{*}{ Ketexangan } \\
\hline & & & Baik & Tidak & \\
\hline 1. & Halaman Axal & Mengablik & Baik & & Berbasil \\
\hline 2. & Halaman Bexanda & Mesapklilis & Baiks & & Berhasil \\
\hline 3. & Halaman Pextanyaan & Mengelilik: & Baik & & Bexhasal \\
\hline 4. & Halaman Tentang & Mengkbik & Baik & & Berhasil \\
\hline 5. & Halaman Kontak & Menglchik & Baik & & Berhasil \\
\hline 6. & Halaman Profil & Mengklik & Baik & & Berhasil \\
\hline 7. & Halaman Awval Admin & Mengklik: & Baik & & Berhasil \\
\hline 8. & $\begin{array}{l}\text { Halaman } \\
\text { Rertanyaan }\end{array}$ & Asengklik & Baiks & & Berhasil \\
\hline
\end{tabular}

\section{Gambar 14 Pengujian}

\section{Pembahasan}

Pada Tahapan ini akan dibahas apakah sistem informasi yang akan dibangun sudah sesuai dengan kebutuhan dan tujuan penelitian. Berdasarkan hasil dan pengujian yang telah dilakukan, sistem informasi aplikasi ini telah berfungsi sesuai kebutuhan fungsional yang telah diuraikan pada analisa kebutuhan. Adapun kebutuhan tersebut antara lain:

a. Sistem Informasi ini adalah aplikasi ini memiliki user dan admin.

b. Sistem Informasi ini menggunakan fitur login untuk membatasi user sistem.

c. Admin sistem informasi ini bisa menambahkan data atau pertanyaan.

d. User dapat melakukan pengauditan dengan pertanyaan-pertanyaan yang ada.

e. User dapat melihat hasil pengauditan yang telah dilakukan sebelumnya.

Berdasarkan tujuan dari penelitian ini yakni, membuat aplikasi pengauditan yang dapat membantu tim auditor Universitas Sam Ratulangi untuk melakukan pengauditan di setiap jurusan yang ada, maka dapat disimpulkan bahwa aplikasi ini telah berhasil dikembangkan dan dapat digunakan. Secara keseluruhan aplikasi ini dapat dijalankan melalui Web. 


\section{PENUTUP}

\section{A. Kesimpulan}

Beberapa kesimpulan yang dapat diperoleh peneliti adalah sebagai berikut: Berdasarkan penelitian yang telah dilakukan, maka dapat diambil kesimpulan:

1. Implementasi Sistem Informasi telah dibuat sesuai dengan perancangan pada bab 4 .

2. Aplikasi ini dapat membantu tim pengaudit mutu akademik Universitas Sam Ratulangi untuk melakukan pengauditan di setiap jurusan yang ada.

\section{B. Saran}

1. Aplikasi ini dapat digunakan dengan baik dan dapat lebih dikembangkan lagi oleh Tim AMAI Universitas Sam Ratulangi.

2. Apapun aplikasi tersebut, diharapkan dapat memberi manfaat bagi tim auditor untuk melakukan pengauditan

\section{DAFTAR PUSTAKA}

[1] Kristanto 2004:10 Pengertian Basis Data Database

[2] Arief 2011 Pengertian Mysql

[3] Swastika 2006. Pengertian PHP

[4] MenurutAdi Nugroho 2005. Pengertian UML

[5] Pressman, Roger S. 2010. Software Engineerin Practitioner's Approach, Seventh Edition. Mc Graw Hill Higher Education.

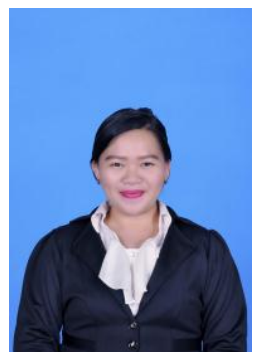

Sekilas dari penulis dengan nama lengkap Viastri Jublincha Pratiwi Rindengan, lahir di kota Tomohon Anak pertama dari dua bersaudara. Dengan pendidikan Sekolah GMIM 2 Tinoor, kemudian melanjutkan ke SMP Kristen Tomohon, kemudian melanjutkan ke SMK Kristen 1 Tomohon setelah lulus tahun 2010 melanjutkan ke Perguruan tinggi tepatnya di Universitas Sam Ratulangi Manado dengan mengambil jurusan Teknik Informatika. Pada tahun 2014 bulan November, penulis membuat skripsi demi memenuhi syarat sarjana (S1) dengan penelitian berjudul Rancang Bangun Aplikasi Audit Mutu Akademik Internal Universitas Sam Ratulangi berbasis web yang dibimbing oleh dua dosen pembimbing yaitu Arie S.M Lumenta ST, MT dan Yaulie D.Y Rindengan ST, MM, MSc sehingga pada tanggal 12 Oktober 2015 penulis resmi lulus di Teknik Informatika Universitas Sam Ratulangi Manado dengan gelar Sarjana Komputer dengan predikat memuaskan. 